\title{
Editorial
}

D.H. Morison MB CH B FRCP(C)

K.G. Smedstad MB CH B FRCP(C)

\section{Continuous infusion epidurals for obstetric analgesia}

Continuous infusion of local anaesthetic for epidural analgesia in obstetrics was first described in 1963. ' However, this method of providing pain relief in labour did not become popular, probably because of the limitation of the mechanical pumps available at that time and also the tachyphylaxis associated with the use of lidocaine or mepivacaine. ${ }^{2}$ Recently, continuous infusions have been described using modern infusion devices and low concentrations of bupivacaine $(0.125-0.375$ per cent) ${ }^{3-10}$ The claimed advantages for this technique over intermittent bolus injections include:

(1) A more stable level of analgesia, because of the elimination of the return of painful contractions, which is the usual indication for a repeat injection of local anaesthetic in the intermittent injection technique.

(2) Lower blood concentrations of local anaesthetic which result from decreased absorption from the epidural space during continuous infusion.

(3) Lower blood concentrations of local anaesthetic if the epidural catheter is inadvertently placed in a vein and a direct intravenous injection is made.

(4) A reduced risk of total spinal block if the epidural catheter is inadvertently positioned in the subarachnoid space.

(5) A reduced incidence of hypotensive episodes due to decreased sympathetic blockade.

In the studies so far reported the rate of acceptable analgesia varied from 70 per cent (infusion rate $6 \mathrm{ml} /$ hour of 0.25 per cent bupivacaine $)^{6.7}$ to $90 \mathrm{per}$ cent $(6 \mathrm{ml} /$ hour of 0.3 per cent or $10 \mathrm{ml} /$ hour of 0.25 per cent bupivacaine).$^{7,8}$ This compares favourably

From the Department of Anaesthesia, McMaster University, 1200 Main Street West, Hamilton, Ontario, L8N $3 Z 5$.

CAN ANAESTH SOC J 1985,32:2/pp 101-4 with epidural analgesia using intermittent injections and comparable doses of bupivacaine. ${ }^{11}$ However, no study comparing infusion and intermittent techniques has been reported and thus it is not known if "acceptable analgesia" means the same in different studies. Until such a study is reported it is not possible to be sure that the continuous infusion epidural technique does provide equivalent, or even better, pain relief in labour in comparison to the intermittent injection technique.

Blood concentrations of bupivacaine (infused at a rate of $10 \mathrm{ml}$ of 0.25 per cent per hour) measured at the time of delivery where a mean of $0.76 \mu \mathrm{g} \cdot \mathrm{ml}^{-1}$ (maternal vein), $0.17 \mu \mathrm{g} \cdot \mathrm{ml}^{-1}$ (umbilical vein) with a foetal maternal ratio of $0.22 .^{8}$ These levels are comparable with previous reports of blood concentration after intermittent injection techniques. ${ }^{12}$

A continuous infusion of bupivacaine might be safer than an intermittent technique if an epidural catheter was inadvertently placed in the CSF, as bolus injections would probably give a higher and more rapid spread of analgesia. However, since a bolus injection (following a test dose) is normally used to establish analgesia, the clinical relevance of this suggested advantage for the continuous infusion technique is limited. At the rates of infusion reported, a total of $15-25 \mathrm{mg}$ of bupivacaine would reach the CSF per hour, which is comparable to the recommended dose of bupivacaine for spinal anaesthesia. ${ }^{13}$ In two cases reported, ${ }^{5}$ there was a slow upward spread of analgesia to the $T_{4}$ level within $60-90$ minutes of infusion of $5 \mathrm{ml} /$ hour of 0.25 per cent bupivacaine, presumably secondary to intrathecal injection. The safety of this technique in such a situation will only be assured by the vigilance of the hospital staff involved in checking the spread of analgesia and other vital signs.

Hypotensive episodes during infusion epidurals varied from 5-8 per cent, ${ }^{5.6}$ which is comparable to 
the reported frequency with intermittent injections. ${ }^{14}$

It is also imperative that the infusion device used for injection of the local anaesthetic should have safety features such as accuracy, an adjustable flow rate which cannot be changed by accident and tubing which does not allow injection of other substances in error. The Intraflo ${ }^{\circledR}$ capillary flow device as used in two studies ${ }^{6,7}$ does not meet these requirements. The flow rate cannot be adjusted, is dependent on the pressure applied to the solution $\mathrm{bag}^{15}$ and also the use of this device involves an adaptation from its original purpose. One infusion pump (IVAC 700) used by the authors and others has been devised particularly for use in epidural anaesthesia and has the above safety features incorporated.

One potential attraction for the use of continuous infusion epidurals is the reduction in the need for experienced personnal to "top-up" the epidural. In fact, in some hospitals this method of epidural management may be easier to institute because nurses are not permitted to "top-up" epidurals and the anaesthetists may not be immediately available to provide this service. However, a continuous infusion epidural does not mean that a lesser degree of patient supervision or a decreased availability of staff experienced in resuscitation is acceptable, as the risks of inadvertent intravascular or intrathecal injection are not decreased. The training of nursing staff in epidural analgesia should be as thorough with this method of infusion as with "top-up" epidurals.

Continuous infusion epidurals for obstetric analgesia may prove to be a useful method for providing analgesia in labour because of the possible advantages such as improved pain relief and increased acceptability by both nursing and anaesthesia staff. However, the use of continuous infusion epidurals has not as yet been proven to be safer or to be associated with a decreased risk of untoward events such as high spinal block or intravascular injection of local anaesthetic.

At present the use of continuous infusion epidurals in obstetrics is being studied by the Standards of Practice Committee of the Canadian Anaesthetists' Society and by a Sub-Committee of the Ontario Medical Association, Section of Anaesthesia.

As noted above, the relative efficacy of the two techniques can only be judged by direct compara- tive studies. With respect to patient safety, it would seem advisable for continuous infusion epidurals to be conducted with the same precautions that are used with intermittent injections, i.e. close monitoring of the patient and immediate availability of appropriate resuscitative measures.

\section{Perfusion épidurale continue pour anal- gésie obstétricale}

La perfusion épidurale continue d'anesthésique local pour l'analgésie obstétricale a été initialement décrite en 1963. ${ }^{1}$ Cependant, cette méthode de fournir un soulagement de la douleur lors du travail n'est pas devenue populaire, probablement à cause des limitations mécaniques des pompes alors disponibles et aussi à cause de la tachyphylaxie associée à l'usage de la lidocaïne ou de la mépivacaine. ${ }^{2}$ Récemment la perfusion continue a été décrite utilisant des appareils d'infusion modernes et de faibles concentrations de bupivacaine $(0.125-0.375$ pour cent).$^{3-10}$ Les avantages attribués à cette technique sur la technique d'injection intermittente de bolus incluent:

1) Un niveau plus stable d'analgésie par suppression du retour des contractions douloureuses qui indiquaient habituellement la nécessité de répéter l'injection d'anesthésique local dans la technique d'injection intermittente.

2) Des concentrations sanguines d'anesthésique local plus basses par une absorption moindre de l'espace épidural lors de la perfusion continue.

3) Des concentrations sanguines d'anesthésique local plus basses si le cathéter épidural est placé par inadvertance dans une veine où une injection intraveineuse directe est faite.

4) Un risque plus faible de rachi totale si le cathéter épidural est positionné par inadvertance dans l'espace sous arachnoïdien.

5) Une diminution de l'incidence des épisodes d'hypotension par un moindre blocage sympathique.

Dans les études rapportées jusqu'ici, le taux d'analgésie acceptable varie de 70 pour cent (débit 